JAMP: Jurnal Adminitrasi dan Manajemen Pendidikan

Volume 2 Nomor 4 Desember 2019, Hal : 213-221

Tersedia Online di http://journal2.um.ac.id/index.php/jamp/

ISSN 2615-8574 (online)

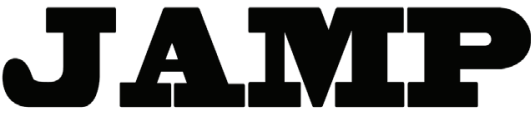

JURNAL ADMINISTRASI DAN MANAJEMEN PENDIDIKAN

\title{
KEPEMIMPINAN KEPALA SEKOLAH DALAM MEMBANGUN CITRA PUBLIK
}

\author{
Dian Erika Putri \\ Ali Imron \\ Asep Sunandar \\ Universitas Negeri Malang \\ dianerikaputri@gmail.com
}

\begin{abstract}
This study aims to describes the public image of SMAN 3 Malang, the leadership of the principal, the strategic steps of the principal, the problems and solutions made in building a public image. This study uses a qualitative approach with a type of case study research. The results of the study include: (1) SMAN 3 Malang has a good or positive image. This image is seen from achievements in the academic and non-academic fields, good school services and alumni ties, (2) The principal acts as the top leader and manager in leading SMAN 3 Malang, the principal has a high commitment and firmness and open minded, and the principal uses Bottom-Up in making decisions, which means analyzing and collecting data first and communicating with the parties involved, (3) SMAN 3 Malang uses the PDCA step in making a good program of activities, namely Plan, Do, Check, and Action. (4) There are problems that lie in the commitment section of some teachers that need to be motivated. In addition, there are problems, namely lack of carrying capacity such as facilities and infrastructure to finance. The solution is to motivate teachers to have a high commitment and take a humanist approach, especially to the community or student guardians so that the carrying capacity can be fulfilled.
\end{abstract}

Keywords: leadership, principal, public image

Abstrak: Tujuan penelitian ini adalah untuk mendeskripsikan citra publik di SMAN 3 Malang, kepemimpinan kepala sekolah, langkah strategis kepala sekolah, serta masalah dan solusi yang dilakukan dalam membangun citra publik. Penelitian ini menggunakan pendekatan kualitatif dengan jenis penelitian studi kasus. Hasil penelitian meliputi: (1) SMAN 3 Malang memiliki citra yang baik atau positif. Citra ini dilihat dari prestasi di bidang akademik dan nonakademik, pelayanan sekolah dan ikatan alumni yang bagus, (2) Kepala sekolah berperan sebagai top leader dan manajer dalam memimpin SMAN 3 Malang, kepala sekolah memiliki komitmen yang tinggi dan sikap tegas dan open minded, serta kepala sekolah menggunakan Bottom-Up dalam pembuatan keputusan, yang artinya menganalisis dan mengumpulkan data terlebih dahulu dan melakukan komunikasi dengan pihak yang terlibat, (3) SMAN 3 Malang menggunakan langkah PDCA dalam pembuatan program kegiatan yang bagus, yaitu Plan, Do, Check, dan Action. (4) Terdapat permasalahan yang terletak pada bagian komitmen beberapa guru yang perlu untuk dimotivasi. Selain itu, terdapat masalah yaitu kurangnya daya dukung seperti sarana dan prasarana hingga finansial. Solusi yang dilakukan yaitu memotivasi guru-guru agar memiliki komitmen yang tinggi serta melakukan pendekatan humanis, terutama ke masyarakat atau wali murid sehingga daya dukung dapat terpenuhi.

Kata kunci: kepemimpinan, kepala sekolah, citra publik

Peran kepala sekolah sebagai pemimpin sangatlah dibutuhkan dalam mengelola dan memajukan sekolah. Kepala sekolah harus memiliki ide-ide yang mampu memajukan sekolah dengan baik, menganalisis peluang ataupun ancaman yang datang. Masalah yang datang hendaknya ditangani secara bersama- 
sama sehingga tujuan organisasi dapat tercapai. Kepala sekolah merupakan bagian penting dimana perannya dalam membuat kebijakan dan mengambil keputusan. Kepala sekolah sebagai kunci atau tonggak bagaimana sekolah dapat berjalan dengan baik atau tidak. Urgensi dari sebuah permasalahan yang ada di sekolah adalah bagaimana langkah-langkah strategis yang digunakan kepala sekolah untuk mengupayakan agar sekolah mampu diterima di masyarakat dengan baik dan bersaing dengan sekolah-sekolah lain melalui citra positif. Ekosiswoyo (2007) menyatakan bahwa faktor kepemimpinan sangat diperlukan dalam mendukung peningkatan kualitas pendidikan, karena gaya atau perilaku yang ditunjukkan oleh pemimpin akan memengaruhi dan menggerakkan individu atau kelompok dalam organisasi yang dipimpinnya.

Berdasarkan uraian di atas, peneliti ingin mengetahui strategi kepala sekolah dalam membangun citra sekolah tersebut sehingga menjadi sekolah favorit di Kota Malang. Membangun menurut KBBI (2019) adalah mendirikan, membina maupun bersifat memperbaiki. Oleh karena itu, peneliti mengambil judul penelitian "Kepemimpinan Kepala Sekolah dalam Membangun Citra Sekolah di SMA Negeri 3 Malang." Peneliti memilih lokasi penelitian di SMA Negeri 3 Malang karena sekolah tersebut adalah sekolah terbaik di kota Malang. Pradana (2016) menyebutkan dalam laman Malangtimes.com bahwa SMAN 3 Malang mendapatkan penghargaan tersebut berdasarkan daftar penghargaan sekolah berintegritas yang dianugerahkan oleh Kementerian Pendidikan dan Kebudayaan Republik Indonesia.

SMAN 3 Malang terletak di pusat kota Malang dan bersebelahan dengan sekolah-sekolah unggul di kota Malang, yaitu SMAN 1 Malang dan SMAN 4 Malang. Animo masyarakat yang cukup tinggi untuk menyekolahkan anaknya di SMA Negeri 3 Malang karena prestasi peserta didik dan kesuksesan alumni. Maka dari itu, secara umum penelitian ini bertujuan untuk mendeskripsikan citra sekolah di SMA Negeri 3 Malang, kepemimpinan kepala sekolah dalam membangun citra sekolah, langkah-langkah strategis kepala sekolah dalam membangun citra sekolah, serta masalah dan solusi yang dilakukan dalam membangun citra sekolah.

\section{METODE}

Pada penelitian ini digunakan pendekatan kualitatif dengan jenis penelitian studi kasus. Teknik pengumpulan data yang digunakan adalah observasi, wawancara dan dokumentasi. Analisis data dilakukan mulai dari pengumpulan data, reduksi data, penyajian data, dan penarikan kesimpulan. Pengecekan keabsahan data dilakukan dengan cara: (1) triangulasi sumber, yaitu pengecekan berasal dari sumber atau informan yang berbeda. Selain itu, triangulasi teknik juga digunakan dengan cara membandingkan data yang diperoleh dari kepala sekolah, waka sekolah, alumni, wali murid, dan peserta didik melalui observasi, wawancara dan dokumentasi; (2) meningkatkan ketekunan dengan bersikap lebih teliti, cermat dan berkesinambungan; (3) kecukupan bahan referensi yang diperoleh melalui catatan lapangan, transkrip wawancara, foto, dan dokumen pendukung; dan adanya (4) member checks dengan cara pemeriksaan melalui cara menanyakan kembali kepada informan apa yang telah direkam atau ditulis dalam catatan lapangan.

\section{HASIL}

\section{Citra Publik di SMAN 3 Malang}

SMAN 3 Malang adalah sekolah favorit di kota Malang yang memiliki citra sekolah yang positif. SMAN 3 Malang memiliki kegiatan yang seimbang antara kegiatan akademik dan nonakademik. Beberapa kegiatan tersebut di antaranya adalah Bedhol Bhawikarsu sebagai kegiatan bakti sosial, PSCS sebagai pagelaran seni, dan olimpiade. Bedhol Bhawikarsu merupakan kegiatan sosial selama tiga hari dua malam di sebuah desa yang mana peserta didik mengabdi untuk kepentingan sosial. Akan tetapi, peserta didik juga diberi kegiatan akademik untuk observasi, menemukan permasalahan, menganalisis dan menyampaikan solusinya. Selain itu, pagelaran seni yang diberi nama sebagai Pagelaran Seni Citra Smanti atau yang biasa disebut dengan PSCS adalah kegiatan tahunan SMAN 3 Malang yang telah dikenal oleh masyarakat luas. Dengan adanya kegiatan PSCS ini, peserta didik turut berperan aktif dalam melancarkan kegiatan, sehingga peserta didik memiliki skills tidak hanya dalam bidang akademik. Skills 
yang dimaksud antara lain adalah adanya pengalaman dan keterampilan dalam mengelola kegiatan mulai dari perencanaan hingga evaluasi dilaksanakan. Selain itu, program unggulan yang lain adalah kantin digitalisasi yang cashless dan program aplikasi tes yang dimiliki.

Terdapat pula ikatan alumni yang kuat, sehingga SMAN 3 Malang merasa terbantu dengan adanya bantuan-bantuan yang berasal dari alumni, seperti beasiswa peserta didik, sumbangan mobil ambulance dan lain-lain. Kegiatan lain yang dilaksanakan oleh alumni adalah Alumni Mengajar. Mereka datang ke sekolah dengan beragam latar belakang, mereka memotivasi peserta didik mengenai pekerjaan, kemudian bagaimana pencapaian yang bisa diraih sampai sekarang. Beragam program yang dilakukan oleh alumni dalam rangka alumni mengajar, misalnya ada seminar dan kajian-kajian keagamaan.

SMAN 3 Malang mengunggulkan sebuah pelayanan yang maksimal. Pelayanan merupakan hal utama bagi sekolah, karena dengan upaya pelayanan prima yang dilakukan, akan muncul sistem yang tertata/teratur. Hal ini yang mampu membuat pelayanan di sekolah dapat berjalan dengan baik dan lancar sehingga menghasilkan inovasi-inovasi yang bagus. Inovasi dalam hal pelayanan yang dimaksud adalah update pelayanan ke arah digitalisasi yang disesuaikan dengan zaman. Pelayanan unggul yang terlihat di SMAN 3 Malang adalah dapat dilihat melalui program yang serba digitalisasi. Program inilah yang menjadi acuan sekolah lain untuk dicontoh karena pelayanannya. Beberapa di antaranya adalah pembayaran di kantin yang cashless, yang mana warga sekolah tidak perlu menggunakan uang secara langsung untuk membayar. Selain itu, adanya program aplikasi tes yang menggunakan sistem online dan memiliki aplikasi sendiri. Program olimpiade, pagelaran seni dan bakti sosial.

Sekolah berusaha melakukan pelayanan yang optimal. Optimal di sini diartikan dengan upaya terbaik yang sekolah dapat lakukan. Adapun keluhan mengenai pelayanan yang tidak bagus dapat disampaikan langsung ke sekolah untuk dijadikan sebagai masukan yang sangat bermanfaat dalam mengelola sistem pelayanan tersebut. Dengan adanya penjelasan dari berbagai informan tersebut, dapat disimpulkan bahwasanya pelayanan merupakan upaya membangun citra sekolah yang dilakukan secara maksimal dan diharapkan akan memberikan sebuah hasil yang memuaskan. Dengan adanya pelayanan prima, nilai-nilai unggul yang dikembangkan, kualitas alumni dan program sekolah yang memiliki banyak program unggul dan disertai dengan adanya pelayanan prima inilah yang membuat masyarakat memiliki persepsi yang baik mengenai citra sekolah.

SMAN 3 Malang memiliki visi, yaitu "Menjadi sekolah unggul yang memiliki civitas akademika yang beriman, bertaqwa, berakhlakul karimah, dan berprestasi serta berperan aktif dalam era global, dan peduli pada lingkungan". Berdasarkan visi tersebut, sekolah memiliki nilai-nilai yang dikembangkan sehingga peserta didik maupun warga sekolah (civitas akademika) memiliki karakter sesuai dengan nilai yang dikembangkan. Nilai-nilai unggul yang dikembangkan oleh sekolah sehingga seluruh warga sekolah diharapkan memiliki karakter yang baik sesuai dengan apa yang dipaparkan di visi, dan selanjutnya diimplementasikan melalui misi-misi yang dilakukan sekolah. Misi tersebut tertuang dalam program-program yang dilakukan sekolah pada satu tahun ajaran. Dapat disimpulkan bahwa terdapat delapan nilai yang dikembangkan oleh SMAN 3 Malang, yaitu (a) religius atau sikap spiritual, (b) kejujuran, (c) berprestasi, (d) keterampilan, (e) kebersamaan, (f) nasionalisme, (g) kegiatan global, dan juga (h) sikap sosial terhadap lingkungan.

\section{Kepemimpinan Kepala Sekolah}

Kepemimpinan merupakan cara pemimpin dalam memengaruhi anggota bawahan untuk mencapai suatu tujuan organisasi. Kepala sekolah, sebagai pemimpin dalam dunia pendidikan memiliki peran yang sangatlah penting di dalam sebuah lembaganya. Ibu Asri Widiapsari telah menjadi kepala SMAN 3 Malang selama 5 tahun sejak 25 September 2014. Peran beliau sebagai kepala sekolah adalah menjadi top leader dan manajer. Posisinya yang sebagai pemimpin sangat diharapkan menjadi pusat pembuatan keputusan. Kepala sekolah menerangkan bahwa untuk mendorong dan memengaruhi anggota dapat berawal dari sesuatu yang sederhana, yaitu kepala sekolah selalu menyontohkan dirinya untuk disiplin dan menjadi teladan sehingga dapat memotivasi anggota. Hal ini dilakukan oleh kepala sekolah karena para anggotanya yang sudah saling memahami tugas (jobdesk) sehingga kepala sekolah tidak harus mendorong atau memengaruhi secara berlebihan. Fungsi dari adanya jobdesk pada struktur organisasi 
yang ada adalah untuk mengetahui tugasnya masing-masing, sehingga cara kepala sekolah untuk mencapai tujuan yang telah ditetapkan adalah dengan memberikan pemahaman yang sesuai kepada bawahan agar mematuhi jobdesk yang telah dibuat.

Kepala sekolah merupakan sosok yang memiliki komitmen tinggi dan memiliki sikap yang tegas. Sikap komitmen yang dimiliki kepala sekolah berhasil memajukan SMAN 3 Malang menjadi lebih baik. Hal ini ditunjukkan dengan adanya prestasi-prestasi di bidang akademik maupun nonakademik yang diraih selama menjabat. Selama menjabat menjadi kepala sekolah sejak tahun 2014, ibu Asri dikenal sebagai sosok yang tegas dalam memimpin sehingga program kegiatan dapat berjalan dengan lancar. Kepala sekolah juga memperhatikan anggotanya sehingga keputusan yang dibuat sudah berdasarkan pertimbangan yang matang. Pada pembuatan keputusan, kepala sekolah tidak sewenang-wenang dalam memberi keputusan kepada anggota-anggotanya. Dalam setiap permasalahan yang ada, kepala sekolah memeriksa dan menganalisis terlebih dahulu apa saja yang dibutuhkan dalam penyelesaiannya.

Kepala sekolah dalam pembuatan keputusan menggunakan cara bottom-up, yaitu di mana sebuah keputusan dibuat berdasarkan analisis dan pengumpulan data terlebih dahulu. Cara ini dilakukan agar keputusan tidak sewenang-wenang karena berdasarkan informasi yang diperoleh dari berbagai sumber. Dalam setiap keputusannya, kepala sekolah melibatkan pihak yang saling terkait. Dapat dikatakan bahwa dalam pembuatan sebuah keputusan, seorang kepala sekolah membutuhkan analisis terlebih dahulu dan membutuhkan komunikasi dengan beberapa pihak sebagai bahan pertimbangan. Komunikasi dilakukan dengan pihak terkait, atau yang biasa disebut dengan tim manajemen. Tim manajemen sekolah terdiri dari waka sekolah, komite maupun perwakilan orangtua.

\section{Langkah Strategis Kepala Sekolah dalam Membangun Citra Publik}

Pada setiap kegiatan di sekolah, pastinya diawali dengan perencanaan dan diakhiri dengan evaluasi. Begitu pula dengan kepala SMAN 3 Malang yang membangun citra positif sekolah dengan melakukan pembuatan program terlebih dahulu. Program dibuat berdasarkan perencanaan yang matang. Perencanaan merupakan langkah dasar untuk membuat program yang bagus. Perencanaan (Plan) di sini dijabarkan dalam bentuk yang namanya RAKS, yaitu rencana anggaran dan kegiatan sekolah. Langkah selanjutnya adalah pelaksanaan (Do) yang mana merupakan implementasi dari seluruh perencanaan yang telah dibuat di dalam RAKS. Proses pelaksanaan dapat dilakukan dalam jangka waktu bulanan, semesteran atau setiap enam bulan dan bahkan ada yang dilakukan dalam jangka waktu tahunan. Untuk langkah Check, sekolah melakukan evaluasi yang biasanya dilaksanakan pada akhir semester. Sekolah melihat apakah program kegiatan dapat berjalan sesuai dengan yang diinginkan atau tidak, dan seberapa tingkat keberhasilannya. Apabila program kegiatan berjalan berjalan dengan lancar, maka untuk seterusnya program akan dijalankan dan ditingkatkan. Sementara itu, bagi program kegiatan yang belum berjalan dengan lancar maka hasil evaluasi ini akan dijadikan sebagai bahan perbaikan di semester berikutnya atau tahun berikutnya. Langkah atau upaya perbaikan inilah yang biasanya masuk ke dalam langkah Action.

SMAN 3 Malang selalu berupaya memberikan pelayanan yang prima melalui berbagai program kegiatan. Program tersebut tidak hanya ditujukan kepada peserta didik, tetapi juga untuk masyarakat luas. Program kegiatan SMAN 3 Malang yang diminati oleh masyarakat adalah segala program kegiatan yang mengarah pada pengembangan peserta didik. Orangtua tertarik apabila program kegiatan tersebut memberikan manfaat pada peserta didik untuk terampil dalam bidang akademik maupun nonakademik. Strategi yang dilakukan SMAN 3 Malang adalah dengan adanya memberikan pelayanan dan komunikasi yang baik, serta memberikan wadah, waktu dan kesempatan bagi siapapun yang ingin berpartisipasi. Komunikasi yang baik juga dilakukan melalui koordinasi dengan para guru dan staf di sekolah.

Ibu Asri selaku kepala sekolah selalu melibatkan berbagai pihak yang terlibat melalui komunikasi atau koordinasi untuk membuat keputusan. Tidak hanya itu, lebih lanjut kepala sekolah menegaskan bahwa strategi yang dilakukan untuk mempertahankan citra sekolah agar selalu bagus di mata masyarakat adalah dengan cara mempertahankan komitmen dan etos kerja. Etos kerja yang dimaksud adalah sikap yang muncul karena kesadaran pribadi sehingga menimbulkan budaya kerja yang sangat 
bagus. Strategi inilah yang ditumbuhkan di dalam lingkungan SMAN 3 Malang sehingga mampu menghasilkan berbagai program kegiatan dan prestasi yang membanggakan. Dapat disimpulkan bahwa langkah strategis kepala sekolah dalam membangun citra publik sekolah adalah dengan: (a) memberikan pelayanan dan komunikasi yang baik, (b) memberikan wadah, waktu dan kesempatan bagi siapapun yang ingin berpartisipasi dan (c) mempertahankan komitmen dan etos kerja. Dengan langkah strategis ini SMAN 3 Malang tidak kalah unggul dengan sekolah lain dan memiliki citra yang bagus di mata masyarakat.

\section{Masalah dan Solusi yang Dilakukan dalam Membangun Citra Publik}

Permasalahan yang terjadi di SMAN 3 Malang adalah bagaimana sekolah mampu mempertahankan dan mengembangkan citra yang bagus tersebut. Hal ini dikarenakan sebuah manajemen atau pengelolaan citra sekolah akan bagus apabila sekolah tersebut mampu mempertahankan dan mengembangkan untuk pembaruan yang lebih bagus. Analisis SWOT yang dilakukan oleh sekolah merupakan langkah perencanaan yang strategis yang dilakukan untuk mengetahui gambaran sekolah. Analisis SWOT terdiri dari Strengths (kekuatan), Weaknesses (kelemahan), Opportunities (peluang), dan juga Threats (ancaman). Kekuatan SMAN 3 itu salah satunya adalah kepercayaan masyarakat dan dukungan alumni. Kelemahannya adalah ketika pencapaian tertinggi, cenderung mulai terlena karena sekolahsekolah lain kan juga bangkit untuk mengejar. Peluangnya adalah anak-anak yang masuk di SMAN 3 Malang merupakan anak pilihan sehingga sekolah memiliki modal yang bagus dan kuat. Modalnya berupa input siswa yang bagus. Sementara itu, ancamannya yaitu kebangkitan dari sekolah-sekolah swasta, dan keinginan untuk sistem penerimaan siswa baru yang tidak lagi memperhitungkan nilai tapi memperhitungkan zonasi. Ini yang merupakan ancamannya.

Permasalahan yang terjadi terletak pada bagian komitmen beberapa guru yang perlu untuk dimotivasi. Selain itu, terdapat masalah yaitu kurangnya daya dukung seperti sarana dan prasarana hingga finansial. Solusi yang dilakukan yaitu memotivasi guru-guru agar memiliki komitmen yang tinggi serta melakukan pendekatan humanis, terutama ke masyarakat atau wali murid sehingga daya dukung dapat terpenuhi.

SMAN3 Malangdalampelaksanaan programmemiliki indikatorkeberhasilan dalammempertahankan citra sekolah yang bagus. Indikator tersebut merupakan capaian yang dapat dijadikan sebagai tolok ukur keberhasilan dalam melaksanakan program kegiatan di SMAN 3 Malang. Indikator keberhasilan program dikatakan berhasil dapat dilihat dari pencapaian tujuan. Tidak hanya itu, keberhasilan program kegiatan dapat dilihat dari kesenjangan yang ada. Kesenjangan dilihat dari perbandingan antara persentase perencanaan dan pelaksanaan. Apabila pelaksanaan program kegiatan tidak jauh berbeda dibandingkan dengan perencanaan, maka program kegiatan tersebut sudah dapat dikatakan berhasil. Hal inilah yang menjadikan perencanaan haruslah benar-benar matang agar pelaksanaan dapat berjalan dengan baik dan sesuai dengan tujuan.

Dapat disimpulkan bahwa SMAN 3 Malang memiliki indikator keberhasilan suatu program kegiatan yang dapat dilihat dari capaian tujuan, tingkat kesenjangan antara perencanaan dan pelaksanaan serta delapan standar yang ada. Indikator tersebut dijadikan sebagai acuan dalam evaluasi, apakah program dapat dilanjutkan dan ditingkatkan ataukah perlu adanya perbaikan terlebih dahulu. Pada proses evaluasi, sekolah melihat apakah program tersebut dapat dilanjutkan dan ditingkatkan ataukah perlu adanya perbaikan terlebih dahulu.

\section{PEMBAHASAN}

SMAN 3 Malang memiliki program-program kegiatan yang melibatkan masyarakat. Beberapa kegiatan tersebut di antaranya adalah Bedhol Bhawikarsu sebagai kegiatan bakti sosial, PSCS sebagai pagelaran seni, dan olimpiade. Hal ini dijelaskan oleh Wiyono, dkk (2018) bahwa salah satu teknik hubungan sekolah dengan masyarakat adalah melibatkan masyarakat. Melibatkan masyarakat bukan sekadar menyampaikan pesan, tetapi lebih dari itu adalah menuntut partisipasi masyarakat dalam pelaksanaan program pendidikan di sekolah. 
Berdasarkan visi SMAN 3 Malang, yaitu "Menjadi sekolah unggul yang memiliki civitas akademika yang beriman, bertaqwa, berakhlakul karimah, dan berprestasi serta berperan aktif dalam era global, dan peduli pada lingkungan". Sekolah memiliki nilai-nilai yang dikembangkan sehingga peserta didik maupun warga sekolah (civitas akademika) memiliki karakter sesuai dengan nilai yang dikembangkan. Adapun nilai-nilai yang dikembangkan tersebut dijelaskan oleh tiga informan. Ketiga pernyataan tersebut menunjukkan adanya nilai-nilai unggul yang dikembangkan oleh sekolah sehingga seluruh warga sekolah diharapkan memiliki karakter yang baik sesuai dengan apa yang dipaparkan di visi, dan selanjutnya diimplementasikan melalui misi-misi yang dilakukan sekolah. Misi tersebut tertuang dalam program-program yang dilakukan sekolah pada satu tahun ajaran. Dapat disimpulkan bahwa terdapat delapan nilai yang dikembangkan oleh SMAN 3 Malang, yaitu (a) religius atau sikap spiritual, (b) kejujuran, (c) berprestasi, (d) keterampilan, (e) kebersamaan, (f) nasionalisme, (g) kegiatan global, dan juga (h) sikap sosial terhadap lingkungan. Hal ini sesuai dengan salah satu prinsip yang dikemukakan oleh Triwiyanto (2015). Prinsip tersebut merupakan hal yang harus diperhatikan dalam merancang dan membangun citra sekolah, yaitu berdasarkan visi dan misi sekolah, artinya upaya pencitraan sekolah harus mengacu pada visi dan misi sekolah.

Pada kepemimpinannya, Kepala sekolah sangat berperan penting dalam membangun citra sekolah. Kepala SMAN 3 Malang memiliki peran sebagai top leader dan manajer sekolah karena posisinya yang memimpin dan mengelola sekolah dengan baik melalui pembuatan keputusan dan yang lainnya. Hal ini seperti yang dikemukakan oleh Duryat (2016) mengenai peranan kepala sekolah. Dalam konteks melakukan perannya sebagai manajer, kepala sekolah diharuskan memiliki ketangkasan dan skills yang dimilikinya untuk mengupayakan dan mendayagunakan berbagai kegiatan yang saling berhubungan untuk mencapai tujuan. Karena dalam proses manajemen diperlukan perencanaan, pengorganisasian, penganggaran, kepemimpinan, dan pengendalian. Selain itu, Suharsaputra (2016) menjelaskan bahwa peran manajerial kepala sekolah sudah tentu diperlukan dalam menjaga organisasi berjalan efektif dan efisien, serta dalam memastikan berbagai kebijakan pendidikan dapat dijalankan dengan baik.

Selama menjabat menjadi kepala sekolah sejak tahun 2014, ibu Asri dikenal sebagai sosok yang tegas dalam memimpin sehingga program kegiatan dapat berjalan dengan lancar. Kepala sekolah juga memperhatikan anggotanya sehingga keputusan yang dibuat sudah berdasarkan pertimbangan yang matang. Dengan penjelasan tersebut, maka kepala sekolah merupakan pemimpin yang memiliki tipe kepemimpinan transformasional. Seperti yang telah disebutkan oleh Rahayu (2018) bahwa ciri implementasi kepemimpinan transformasional kepala sekolah, yaitu menjadi teladan yang baik dan menumbuhkan kebanggan warga sekolah. Selain itu, kepala sekolah membangkitkan semangat, memberikan perhatian dan kepercayaan bagi warga sekolahnya. Hal yang sama dinyatakan oleh Manktelow \& Carlson (dalam Mustiningsih, 2013) bahwa kepemimpinan transformasional (Transformational leadership) adalah tipe pemimpin yang berpikir ke depan, dan memiliki inisiatif terhadap nilai-nilai baru yang memengaruhi organisasinya. Pemimpin tipe ini tegas akan tetapi tidak berbuat sewenang-wenang dalam pembuatan keputusan.

Kepala sekolah menggunakan cara bottom-up, yaitu di mana sebuah keputusan dibuat berdasarkan analisis dan pengumpulan data terlebih dahulu. Cara ini dilakukan agar keputusan tidak sewenang-wenang karena berdasarkan informasi yang diperoleh dari berbagai sumber. Dalam setiap keputusannya, kepala sekolah melibatkan pihak yang saling terkait. Hal ini juga ditambahkan oleh kepala sekolah mengenai cara beliau dalam membuat keputusan seperti berikut. Dapat dikatakan bahwa dalam pembuatan sebuah keputusan, seorang kepala sekolah membutuhkan analisis terlebih dahulu dan membutuhkan komunikasi dengan beberapa pihak sebagai bahan pertimbangan. Komunikasi dilakukan dengan pihak terkait, atau yang biasa disebut dengan tim manajemen. Tim manajemen sekolah terdiri dari waka sekolah, komite maupun perwakilan orangtua.

Hal ini sesuai penuturan Asmani (2012) bahwa keputusan yang baik dan benar tidak boleh dibuat secara semena-mena. Maka dari itu, beberapa tips pengambilan keputusan yang tepat, adalah dengan: (1) Menggunakan Mekanisme Musyawarah, (2) Meminta Masukan dan (3) Menggunakan Feeling. Sementara itu, menurut Wahab (2011) pembuatan keputusan di dalam suatu organisasi merupakan hasil suatu proses komunikasi dan partisipasi yang terus menerus dari keseluruhan organisasi. Pembuatan 
keputusan bisa dilakukan sendiri oleh pemimpin atau melibatkan parisipasi seluruh elemen dengan tetap menjaga komunikasi.

Program kegiatan SMAN 3 Malang yang diminati oleh masyarakat adalah segala program kegiatan yang mengarah pada pengembangan peserta didik. Orangtua tertarik apabila program kegiatan tersebut memberikan manfaat pada peserta didik untuk terampil dalam bidang akademik maupun nonakademik. Hal tersebut menjadi strategi tersendiri bagi SMAN 3 Malang dalam membangun citra publik. Hal ini dijelaskan oleh Triwiyanto (2015) upaya atau strategi yang dapat dilakukan sekolah untuk melakukan pencitraan publik adalah: (1) Peningkatan kerja kepala sekolah, pendidik, dan tenaga kependidikan; (2) Keikutsertaan sekolah dalam kegiatan-kegiatan lomba sekolah dan siswa, misalnya mengikuti olimpiade-olimpiade; (3) Membangun jaringan kerja (network) dengan orangtua peserta didik dan masyarakat. Misalnya pada sekolah menengah kejuruan sekolah membangun kerjasama dengan dunia usaha/dunia industri; (4) Peningkatan layanan akademik dan non-akademik yang prima. Sekolah seharusnya memberikan pelayanan prima terhadap semua orang yang membutuhkan pelayanan sekolah, baik itu personil sekolah maupun pihak luar sekolah; dan (5) Kepemilikan peringkat akreditasi sekolah yang baik. Jika sekolah memiliki akreditasi yang baik maka kesan di masyarakat akan baik pula.

Sekolah sebagai lembaga pendidikan formal tidak terlepas dari pembuatan sebuah program kerja. Hal ini dilakukan agar proses pembelajaran dapat berjalan secara efektif dan efisien untuk mencapai baik itu visi, misi maupun tujuan yang telah ditentukan. SMAN 3 Malang memiliki langkah-langkah yang dilakukan dalam pembuatan program kegiatan. Langkah-langkah inilah yang nantinya akan berdampak pada citra sekolah yang bagus apabila pelaksanaan program kegiatan dapat berjalan dengan baik. Adapun langkah pembuatan program kegiatan dijabarkan pada proses plan, do, check, dan action (PDCA).

Perencanaan (Plan) di sini dijabarkan dalam bentuk yang namanya RAKS, yaitu rencana anggaran dan kegiatan sekolah. Langkah selanjutnya adalah pelaksanaan (Do) yang mana merupakan implementasi dari seluruh perencanaan yang telah dibuat di dalam RAKS. Proses pelaksanaan dapat dilakukan dalam jangka waktu bulanan, semesteran atau setiap enam bulan dan bahkan ada yang dilakukan dalam jangka waktu tahunan. Untuk langkah Check, sekolah melakukan evaluasi yang biasanya dilaksanakan pada akhir semester. Sekolah melihat apakah program kegiatan dapat berjalan sesuai dengan yang diinginkan atau tidak, dan seberapa tingkat keberhasilannya. Apabila program kegiatan berjalan berjalan dengan lancar, maka untuk seterusnya program akan dijalankan dan ditingkatkan. Sementara itu, bagi program kegiatan yang belum berjalan dengan lancar maka hasil evaluasi ini akan dijadikan sebagai bahan perbaikan di semester berikutnya atau tahun berikutnya. Langkah atau upaya perbaikan inilah yang biasanya masuk ke dalam langkah Action.

Hal ini sesuai dengan pendapat Rangkayo (2013) bahwa PDCA adalah singkatan dari Plan, Do, Check, dan Action yaitu siklus peningkatan proses (Process Improvement) yang berkesinambungan atau secara terus menerus seperti lingkaran yang tidak ada akhirnya. Rangkayo (2013) menyebutkan prosedur PDCA meliputi: (1) Plan. Tahapan ini meminta meletakkan sasaran dan proses yang dibutuhkan untuk memberikan hasil yang sesuai. Perlu adanya perencanaan dari masalah yang ada, dan langkah-langkah yang akan diambil; (2) Do. Melakukan apa yang telah direncanakan dan dicanangkan pada tahap sebelumnya. Proses kerja disini mengacu pada jadwal yang sudah dibuat, serta melibatkan orang yang terkait; (3) Check. Langkah selanjutnya untuk menguji hasil perbaikan yang telah dikerjakan, di mana aktivitas kerja perlu dievaluasi dan direview. Apakah hasil yang diraih seudah sesuai target rencana, atau masih ada penyimpangan; dan (4) Act. Yaitu standarisasi hasil perbaikan agar dapat dipergunakan secara berkesinambungan. Langkah ini menjadi langkah pertama kembali untuk melihat improvement baru yang bisa dikerjakan.

Permasalahan yang terjadi di SMAN 3 Malang adalah bagaimana sekolah mampu mempertahankan dan mengembangkan citra yang bagus tersebut. Hal ini dikarenakan sebuah manajemen atau pengelolaan citra sekolah akan bagus apabila sekolah tersebut mampu mempertahankan dan mengembangkan untuk pembaruan yang lebih bagus. Selain itu, bapak Basuki menjelaskan kelemahan dan kelebihan SMAN 3 Malang melalui analisis SWOT. Analisis SWOT merupakan langkah perencanaan yang strategis 
yang dilakukan untuk mengetahui gambaran sekolah. Analisis SWOT terdiri dari Strengths (kekuatan), Weaknesses (kelemahan), Opportunities (peluang), dan juga Threats (ancaman).

Terdapat permasalahan yang terletak pada bagian komitmen beberapa guru yang perlu untuk dimotivasi. Selain itu, terdapat masalah yaitu kurangnya daya dukung seperti sarana dan prasarana hingga finansial. Solusi yang dilakukan yaitu memotivasi guru-guru agar memiliki komitmen yang tinggi serta melakukan pendekatan humanis, terutama ke masyarakat atau wali murid sehingga daya dukung dapat terpenuhi.

Hal ini sebagaimana yang dipaparkan oleh Mustiningsih (2013) bahwa untuk mengatasi masalah, pemimpin harus memiliki kemampuan interpersonal serta teknik komunikasi yang baik sehingga mampu untuk memotivasi anggotanya. Dalam mengatasi permasalahan yang terjadi, kepala SMAN 3 Malang langkah strategis kepala sekolah dalam membangun citra publik sekolah adalah dengan memberikan pelayanan dan komunikasi yang baik, memberikan wadah, waktu dan kesempatan bagi siapapun yang ingin berpartisipasi serta mempertahankan komitmen dan etos kerja. Dengan langkah strategis ini SMAN 3 Malang tidak kalah unggul dengan sekolah lain dan memiliki citra yang bagus di mata masyarakat. Selain itu, Kurniawan (2018) menjelaskan bahwa system komunikasi interpersonal merupakan system komunikasi utama, jejaring social dan komunikasi elektronik menjadi pendukung utama dalam pengembangan komunikasi. Sementara itu, dalam hal mengatasi permasalahan yang ada, Wiyono, dkk (2018) juga mengatakan bahwa masyarakat dapat berpartisipasi dalam bidang keuangan dan sarana prasarana. Dalam bidang keuangan, masyarakat dapat mengusahakan bantuan keuangan, memperlancar biaya SPP dan memberi dana bantuan untuk pelaksanaan pendidikan. sementara itu, dalam bidang sarana dan prasarana masyarakat dapat berpartisipasi dengan jalan menyumbangkan tanah, bahan atau peralatan pendidikan, dan mengusahakan dukungan lainnya.

\section{SIMPULAN DAN SARAN}

Kesimpulan dari penelitian ini meliputi: (1) SMAN 3 Malang memiliki citra yang baik atau positif. Citra ini dilihat dari prestasi di bidang akademik dan nonakademik, pelayanan sekolah dan ikatan alumni yang bagus; (2) Kepala sekolah berperan sebagai top leader dan manajer dalam memimpin SMAN 3 Malang, kepala sekolah memiliki komitmen yang tinggi dan sikap tegas dan open minded, serta kepala sekolah menggunakan Bottom-Up dalam pembuatan keputusan, yang artinya menganalisis dan mengumpulkan data terlebih dahulu dan melakukan komunikasi dengan pihak yang terlibat; (3) SMAN 3 Malang menggunakan langkah PDCA dalam pembuatan program kegiatan yang bagus, yaitu Plan, Do, Check, dan Action. Plan dijabarkan dalam bentuk yang namanya RAKS, yaitu rencana anggaran dan kegiatan sekolah. Do merupakan implementasi dari seluruh perencanaan yang telah dibuat di dalam RAKS. Proses pelaksanaan dapat dilakukan dalam jangka waktu bulanan, semesteran atau setiap enam bulan dan bahkan ada yang dilakukan dalam jangka waktu tahunan. Pada langkah Check, sekolah melakukan evaluasi yang biasanya dilaksanakan pada akhir semester. Apabila program kegiatan berjalan dengan lancar, maka akan dipertahankan dan ditingkatkan. Sementara itu, bagi program kegiatan yang belum berjalan dengan lancar maka hasil evaluasi ini akan dijadikan sebagai bahan perbaikan di semester berikutnya atau tahun berikutnya. Langkah atau upaya perbaikan inilah yang biasanya masuk ke dalam langkah Action. Selain itu, Langkah strategis kepala sekolah dalam membangun citra publik sekolah adalah dengan memberikan pelayanan dan komunikasi yang baik, memberikan wadah, waktu dan kesempatan bagi siapapun yang ingin berpartisipasi serta mempertahankan komitmen dan etos kerja; dan (4) Terdapat permasalahan yang terletak pada bagian komitmen beberapa guru yang perlu untuk dimotivasi. Selain itu, terdapat masalah yaitu kurangnya daya dukung seperti sarana dan prasarana hingga finansial. Solusi yang dilakukan yaitu memotivasi guru-guru agar memiliki komitmen yang tinggi serta melakukan pendekatan humanis, terutama ke masyarakat atau wali murid sehingga daya dukung dapat terpenuhi.

Berdasarkan simpulan di atas, ketiga saran tersebut adalah: (1) Bagi kepala sekolah, dalam melaksanakan tugas sebagai pemimpin dan manajer sebaiknya mampu mempertahankan citra sekolah dengan baik dan meningkatkan program kerja yang inovatif; (2) Bagi orangtua/wali peserta didik, sebaiknya melihat dan memilih sekolah yang mampu membangun citra publik dengan baik sehingga 
orangtua/wali dapat memercayakan peserta didik sepenuhnya kepada pihak sekolah; (3) Bagi peneliti lain yang memiliki tema penelitian yang sama, sebaiknya lebih menambah waktu pengamatan agar data yang diperoleh semakin banyak dan lebih banyak temuan yang diperoleh.

\section{DAFTAR RUJUKAN}

Asmani, J.M. 2012. Tips Menjadi Kepala Sekolah Profesional. Yogyakarta: Diva Press.

Duryat, M. 2016. Kepemimpinan Pendidikan (Meneguhkan Legitimasi dalam Berkontestasi di Bidang Pendidikan). Bandung: Alfabeta.

Ekosiswoyo, R. 2007. Kepemimpinan Kepala Sekolah yang Efektif Kunci Pencapaian Kualitas Pendidikan. Jurnal Ilmu Pendidikan, 14(20), 76-82. Dari https://doi.org/10.1177/1942602X18778291.

KBBI Daring. 2019. Arti Membangun. (Online), (https://kbbi.kemdikbud.go.id/entri/membangun) diakses 8 Juli 2019.

Kurniawan, Y. A. 2018. Kepemimpinan Kepala Sekolah: Suatu Studi Kasus. Jurnal Manajemen dan Supervisi Pendidikan, 2(2), 137-146. Dari http://journal2.um.ac.id/index.php/jmsp/article/view/945/1861.

Mustiningsih. 2013. Pengantar Kepemimpinan Pendidikan. Malang: Fakultas Ilmu Pendidikan Universitas Negeri Malang.

Pradana, A. 2016. SMAN 3 Malang Masuk 10 Besar Sekolah Terbaik Se Indonesia. (Online), (https://www. malangtimes.com/baca/8525/20160109/144500/sman-3-malang-masuk-10-besar-sekolah-terbaik-seindonesia) diakses 28 Maret 2019

Rahayu, R. S. 2018. Implementasi Kepemimpinan Transformasional Kepala Sekolah Dasar Negeri. Jurnal Manajemen dan Supervisi Pendidikan, 2(3), 192-201. Dari http://journal2.um.ac.id/index.php/jmsp/article/ view/4653/2617.

Rangkayo. 2013. Konsep PDCA sebagai Model Mencari Akar Masalah Bisnis. (Online), (http://ikhtisar.com/ konsep-pdca-mencari-akar-masalah/) diakses 20 Juni 2019.

Suharsaputra, U. 2016. Kepemimpinan Inovasi Pendidikan (Mengembangkan Spirit Entrepreneurship Menuju Learning School). Bandung: Refika Aditama.

Triwiyanto, T. 2015. Membangun Citra Sekolah. (Online), (http://mbscenter.or.id/site/page/id/390) diakses 15 februari 2019.

Wahab, A. A. 2011. Anatomi Organisasi dan Kepemimpinan Pendidikan. Bandung: Alfabeta.

Wiyono, B. B., dkk. 2018. Manajemen Hubungan Sekolah Masyarakat. Malang: Universitas Negeri Malang. 